American University Washington College of Law

Digital Commons @ American University Washington College of

Law

Articles in Law Reviews \& Other Academic Journals

Scholarship \& Research

1983

International Legal Standards Relating to the Rights of Aliens and Refugees and United States Immigration Law

Robert K. Goldman

Follow this and additional works at: https://digitalcommons.wcl.american.edu/facsch_lawrev

Part of the Human Rights Law Commons, Immigration Law Commons, and the International Law Commons 


\title{
International Legal Standards Relating to the Rights of Aliens and Refugees and United States Immigration Law
}

\author{
Robert Kogod Goldman and Scott M: Martin
}

The large influx of refugees and undocumented aliens into the United States in recent years has focused renewed public attention on the existing laws relating to the admission, exclusion, and rights of aliens and refugees and has led the Congress and private organizations to undertake a thorough, ongoing review of these laws. At the same time, however, little or no attention has been paid to the rights accorded these persons under international law, despite the fact that the worldwide refugee crisis and the plight of undocumented aliens are among the most serious human rights problems facing the international community today.

The purpose of this paper is to examine the basic international law standards relating to the rights of aliens and refugees, and to assess the compatibility of existing United States laws with those standards. The first section of the paper briefly reviews the status of the individual under contemporary international law and notes the origins of the present obligation of states to respect, on a nondiscriminatory basis, the basic human rights of all persons in their territory. The second section identifies provisions in key international instruments which affect the rights of aliens and refugees and, in particular, analyzes the meaning and legal significance of the right to emigrate, the right of asylum, and the principle of non-refoulement. The third section discusses certain provisions in existing United States immigration law which may be incompatible with basic international legal standards, in particular those which conflict with provisions in conventions and other international documents that the United States has voted for, signed, and/or ratified. Recommended steps that the United States should undertake to harmonize its existing and future immigration and refugee policies with its international obligations are suggested in the conclusion of this paper. 


\section{THE INDIVIDUAL AND ALIEN'S RIGHTS AS PART OF INTERNATIONAL HUMAN RIGHTS LAW}

One of the more significant aspects of international human rights law has been the modification of the traditional international law principle which held that states, and not individuals, are the sole and exclusive subjects of the law of nations. According to the traditional view, a state's treatment of its own citizens was regarded as beyond the purview of international law. ${ }^{1}$ Contemporary international law and practice, however, clearly recognize that the individual is not only a legitimate subject, but is in fact the ultimate object of international law. The basic goal of international human rights law, as F. V. Garcia-Amador has written, "is to ensure the protection of the legitimate interests of the human person, irrespective of his nationality. Whether the person concerned is a citizen or an alien is then immaterial: human beings, as such, are under the direct protection of international law. ${ }^{2}$

Thus, in addition to requiring a state to respect the basic human rights of its citizens, international law today imposes an obligation on states to accord to aliens within their jurisdiction the equal protection of these basic rights. In this regard, the United Nations Charter, ${ }^{3}$ which entered into force in 1945 , states in Article 55 that one of the organization's purposes, inter alia, is to cooperate in promoting and encouraging "universal respect for, and observance of, human rights and fundamental freedoms for all without distinction as to race, sex, language, or religion. ${ }^{4}$ By Article 56, all member states "pledge themselves to take joint and separate action in cooperation with the Organization for the achievement of the purposes set forth in Article 55." 5 The term "pledge" in Article 56 has been interpreted to mean that member states have accepted an international obligation. For example, in its 1971 opinion on Namibia, the International Court of Justice ruled that the human rights provisions of the United Nations Charter are directly binding on member states. ${ }^{6}$ The principle of nondiscrimination in the protection of

1. See, e.g., L. Oppenheim, International Law: A Treatise 362-69 (2d ed. 1912).

2. Garcia-Amador, "Violations of Human Rights and International Responsibility," in L. Sohn \& T. Buergenthal, International Protection of Human Rights 132 (1973).

3. 1946-1947 U.N.Y.B. pt. 3, app. 1 [hereinafter cited as U.N. Charter].

4. Id. art. 55.

5. Id. art. 56.

6. Legal Consequences for States of the Continued Presence of South Africa in Namibia (South West Africa) Not Withstanding Security Council Resolution 276 (1970), 1971 I.C.J. 16 (Advisory Opinion). The court stated:

In order to determine whether the laws and decrees applied by South Africa in Namibia . . . constitute a violation of the purposes and principles of the Charter of the United Nations, the question of intent or government discretion is not relevant; nor is it necessary to investigate or determine the effects of those measures upon the welfare of the inhabitants.

Id. at 57 . The court ruled that the apartheid policies of South Africa, by their terms, violated the human rights clauses of the U.N. Charter.

Under the Charter of the United Nations, [South Africa] had pledged itself to observe and 
human rights is similarly enshrined in the 1948 Charter of the Organization of American States.7 Article 3(j) of Chapter I of the Charter states: "The American States proclaim the fundamental rights of the individual without distinction as to race, nationality, creed or sex." ${ }^{8}$ Although neither the U.N. nor the O.A.S. explicitly defined in its constitutive charters the basic human rights that its respective member states undertook to respect, both organizations issued declarations in 1948 which enumerate and in large measure provide the substantive content of those rights. These two documents are the Universal Declaration of Human Rights ${ }^{9}$ and the American Declaration of the Rights and Duties of Man. ${ }^{10}$

The preamble of the Universal Declaration, referring to the pledge of U.N. member states to promote universal respect for and observance of "human rights and fundamental freedoms," " states: "Whereas a common understanding of these rights and freedoms is of the greatest importance for the full realization of this pledge, Now, therefore, the General Assembly Proclaims this Universal Declaration of Human Rights." 12 The use of the words "a common understanding of these rights and freedoms" clearly suggests that this Declaration was intended to be declarative of and to interpret the term "human rights and fundamental freedoms" mentioned in the U.N. Charter. ${ }^{13}$ The Universal Declaration was adopted by the General Assembly without a dissenting vote on 10 December $1948 .{ }^{14}$ Approximately seven months before, on 2 May 1948, the member states of the O.A.S. signed the

respect ... human rights and fundamental freedoms for all without distinction as to race. To establish instead, and to enforce, distinctions, exclusions, restrictions and limitations exclusively based on grounds of race, colour, descent or national or ethnic origin which constitute a denial of fundamental human rights is a flagrant violation of the purposes and principles of the Charter.

Id. See also Separate Opinion of Vice-President F. Ammoun, id. at 75-79 (discussion of the binding nature of human rights norms).

7. Charter of the Organization of the American States, 2 U.S.T. 2394, T.I.A.S. 2361, as amended by the Protocol of Buenos Aires of 1967, 21 U.S.T. 607, T.I.A.S. 6847 [hereinafter cited as O.A.S. Charter].

8. Id. art. 3(j) (art. 5(j) in original Charter).

9. Adopted 10 December 1948; G.A. Res. 217 A (III), U.N. Doc. AV810, reprinted in 2 U.N. Resolutions, ser. 1, General Assembly 135-43 (D. Djonovich, ed. 1948-49) thereinafter cited as Universal Declaration].

10. Adopted 2 May 1948, by the Ninth International Conference of American States, Bogota, Colombia; reprinted in Inter-American Commission on Human Rights, Handbook of Existing Rules Pertaining to Human Rights, O.A.S. Doc. OEA/Ser. L/V/II.50, doc. 6 (1980) [hereinafter cited as American Declaration].

11. Universal Declaration, supra note 9 , Protocol at 136 . For a discussion of this pledge, see supra notes 4 and 5 and accompanying text.

12. Universal Declaration, supra note 9 , Protocol at 136 (italics omitted).

13. The term "human rights and fundamental freedoms" appears in article 55 of the United Nations Charter. See supra note 4 and accompanying text.

14. Forty-eight states voted in support of G.A. Res. 217 A (III), with two states absent (Honduras and Yemen), and eight abstentions (Saudi Arabia, South Africa, the U.S.S.R., Byelorussian S.S.R., Ukrainian S.S.R., Czechoslovakia, Poland, and Yugoslavia). 2 U.N. Resolutions, ser. 1, General Assembly 29 (D. Djonovich, ed. 1948-49). 
American Declaration of the Rights and Duties of Man. ${ }^{15}$ This document, reflecting natural law theory, asserts that the fundamental rights of man "are not derived from the fact that he is a national of a certain state, but are based upon attributes of his human personality." ${ }^{16} \mathrm{It}$ notes, moreover, that international protection of these rights "should be the principal guide of an evolving American law" and that the American states should "increasingly strengthen [their regional] system in the international field as conditions become more favorable." 17

The fact that both the U.N. and O.A.S. chose in 1948 not to fashion their respective declarations in treaty form, which would have created binding legal obligations, does not mean, however, that the basic rights and freedoms proclaimed in these declarations are merely "aspirational" and without legal effect today. On the contrary, a convincing argument can be made that, with the passage of over thirty years since their adoption, the Universal and American Declarations embody normative principles that have acquired over time the status of international and regional customary law and general principles of law recognized by civilized nations. In this connection, the U.N.'s Office of Legal Affairs made the following observation in a 1962 memorandum:

In United Nations practice, a "declaration" is a formal solemn instrument, suitable for rare occasions when principles of great and lasting importance are being enunciated, such as the Declarations of Human Rights....

[A declaration] may be considered to impart on behalf of the organ adopting it, a strong expectation that Members of the international community will abide by it. Consequently, insofar as the expectation is gradually justified by State practice, a declaration may by custom become recognized as laying down rules binding upon the States. ${ }^{18}$

Similarly, the Inter-American Commission on Human Rights, whose function it is to investigate violations of the rights guaranteed in the American Convention on Human Rights, ${ }^{19}$ has taken the position in recent years that the human rights proclaimed in the 1948 American Declaration are

15. The American Declaration on the Rights and Duties of Man, supra note 10, was adopted by the Ninth International Conference of American States, held at Bogota, Colombia, 30 March-2 May 1948.

16. American Declaration, supra note 10, at 19.

17. Id.

18. 34 U.N. ESCOR Supp. No. 8 at 15, U.N. Doc. E/CN.4/L.604 (1962).

19. Signed 22 November 1969, O.A.S. Doc. OEA/Ser. KIXVI/1.1, doc. 65 rev. 1 corr. 1 (1970), entered into force 18 July 1979 [hereinafter cited as American Convention]; reprinted in Inter-American Commission on Human Rights, Handbook of Existing Rules Pertaining to Human Rights, O.A.S. Doc. OEA/Ser. L/V/II.50, doc. 6 (1980). The American Convention, Resolution XXIV of the Inter-American Conference on Human Rights, was adopted by the Second Special Inter-American Conference, held in Rio de Janeiro, Brazil, 17-30 November 1965. 
part of the hemisphere's customary law and thus legally binding on all O.A.S. member states.

Moreover, the U.S. government in its amicus brief filed with the Court of Appeals for the Second Circuit in the case Filartiga v. Pena ${ }^{20}$ unequivocally stated that certain basic human rights constitute today rules of customary international law that are binding on all nation-states. ${ }^{21}$ In that case, the district court had dismissed the complaint on the assumption that the death by torture of a foreign citizen at the hand of an agent of the same country did not violate the law of nations as that term is used in 28 U.S.C. $\$ 1350.22$ In arguing that official torture is a violation of international law giving rise to a judicially enforceable tort remedy in U.S. courts, the U.S. government noted that "changing customs and standards of behavior in the international community" have "produced wide recognition that certain fundamental human rights are now guaranteed to individuals as a matter of customary international law." 23

While conceding that not all human rights may be judicially enforceable since they lack the requisite degree of "specificity and universality," 24 the government stated that "international custom . . . indicates that nations have accepted as law an obligation to observe fundamental human rights" 25 and that the obligation "has been reiterated in a growing number of more specific multilateral treaties." 26 The government's brief also cites the International Court of Justice's decisions in the Nuclear Test cases (Australia v. France) ${ }^{27}$ and its Advisory Opinion on Namibia ${ }^{28}$ to confirm the existence of a customary law of human rights. The government stated, moreover:

General principles of law recognized by civilized nations also establish that there are certain fundamental human rights to which all individuals are entitled, regardless of nationality. Although specific practices differ widely among nations, all nations with organized legal systems recognize constraints on the power of the state to invade their citizens' human rights. In the period 1948-1973, the constitutions or other important laws of over 75 states either expressly referred to or

20. 630 F.2d 876 (2d Cir. 1980).

21. Brief for United States as Amicus Curiae at 5-12, Filartiga v. Pena-Irala, 630 F.2d 876 (2d Cir. 1980) ("certain fundamental human rights are now guaranteed to individuals as a matter of customary international law").

22. Filartiga v. Pena-Irala, Civil Case No. $79-917$ (E.D. N.Y., filed 6 April 1979).

23. Brief for United States as Amicus Curiae at 6, Filartiga v. Pena-Irala, 630 F.2d 876 (2d Cir. 1980).

24. $I d$.

25. Id. at 9.

26. Id.

27. Australia v. France, Judgment of 20 December 1974, 1974 I.C.). 253, 303 (Opinion of Judge Petren), cited in Brief for United States as Amicus Curiae at 11, n. 20, Filartiga v. Pena-Irala, 630 F.2d 876 (2d Cir. 1980).

28. Advisory Opinion on Legal Consequences for States of the Continued Presence of South Africa in Namibia (South West Africa) Notwithstanding Security Council Resolution 276 (1970), 1971 1.C.J. 16, cited in Brief for United States as Amicus Curiae at 11, n. 20, Filartiga v. Pena-Irala, 630 F.2d 876 (2d Cir. 1980). 
clearly borrowed from the Universal Declaration of Human Rights. In the same period, the Declaration was referred to in at least 16 cases in domestic courts of various nations.

The decisions of the International Court of Justice also reflect and confirm the existence of a customary international law of human rights. ... In sum, as the Department of State said in a recent report to Congress on human rights practices:

There now exists an international consensus that recognizes basic human rights and obligations owed by all governments to their citizens. ... There is no doubt that these rights are often violated; but virtually all governments acknowledge their validity. ${ }^{29}$

The coincidence of views of the U.N.'s legal branch and the U.S. government, which are supported by the writings of numerous international law experts, are strong evidence that many of the principles proclaimed in the Universal and American Declarations have crystallized into binding rules of customary international law and principles of law recognized by nations.

\section{BASIC RIGHTS OF ALIENS AND REFUGEES UN!DER INTERNATIONAL LAW}

Both the Universal and American Declarations proclaim certain rights and freedoms that are relevant to aliens, in general, and to refugees, in particular.

\section{A. The Right to Emigrate}

Article 13 of the Universal Declaration expressly recognizes as a basic human right the individual's right to emigrate. ${ }^{30}$ Article $13(1)$ states that "[e]veryone has the right to freedom of movement and residence within the borders of each state," 31 and 13(2) provides that "[e]veryone has the right to leave any country, including his own, and to return to his country." 32 The American Declaration implicitly proclaims this right in Article 19, which declares: "Every person has the right to the nationality to which he is entitled by law and to change it, if he so wishes, for the nationality of any other country that is willing to grant it to him." ${ }^{\prime 3}$

This new right to emigrate has been incorporated in various international and regional human rights agreements which are legally binding on contracting states parties. For example, Article 12(2) of the International

29. Brief for United States as Amicus Curiae at 10-11 (citations omitted), Filartiga v. PenaIrala, 630 F.2d 876 (2d Cir. 1980).

30. Universal Declaration, supra note 9, art. 13.

31. Id. art. 13(1).

32. Id. art. 13(2).

33. American Declaration, supra note 10, art. 19. 
Covenant on Civil and Political Rights ${ }^{34}$ declares that "[e]veryone shall be free to leave any country, including his own." ${ }^{35}$ Article 5(d)(ii) of the International Convention on the Elimination of All Forms of Racial Discrimination, ${ }^{36}$ Article 22 of the American Convention on Human Rights, ${ }^{37}$ and Article 2(2) of Protocol No. 4 to the European Convention for the Protection of Human Rights and Fundamental Freedom $\mathrm{s}^{38}$ embody this right in almost identical language.

It is important to note that the right to emigrate from one country does not create an express individual right to immigrate to another country. Traditionally, international law has regarded the subject of immigration as preeminently within the exclusive domain of a state's domestic jurisdiction, since it was regarded as a matter concerning the self-interests of states. Thus, in the absence of treaty obligations, a state enjoys the sovereign right to exclude aliens from its territory. The corollary, of course, is that every state can admit anyone it so chooses to its territory. It was only when aliens were admitted to the territory of another state that customary international law sought to protect them and, in particular, their property from arbitrary and discriminatory action by the admitting state. Actual state practice over the past two centuries has exhibited a clear disinclination on the part of many states to exercise this exclusionary power. States have chosen to admit large numbers of aliens into their territory, albeit often on a discriminatory basis; and, motivated by humanitarian considerations, have granted refuge to certain classes of aliens fleeing from persecution. Reflecting this state practice and responding to a series of worldwide refugee crises since 1945, the international community, in connection with its efforts to promote and advance human rights, has sought to accord a greater degree of legal protection to refugees. This has been achieved by the inclusion, as in the case of the right to emigrate, of the right to territorial asylum and the principle of nonrefoulement (nonreturn of a refugee to a country where he has good reason to fear persecution) in numerous international and regional human rights documents and conventions. ${ }^{39}$

34. Opened for signature 19 December 1966, entered into force 23 March 1976; G.A. Res. 2200 A (XXI), 21 U.N. GAOR Supp. No. 16 at 52, U.N. Doc. AV6316 (1966).

35. Id. art. 12(2). Article 12(4) provides: "No one shall be arbitrarily deprived of the right to enter his own country."

36. Opened for signature 7 March 1966, entered into force 4 January 1969; 660 U.N.T.S. 195 (1969); G.A. Res. 2106 A (XX), 20 U.N. GAOR Supp. No. 4 at 47-51, U.N. Doc. A/6014 (1965).

Article 5(d)(ii) provides that all states parties undertake to eliminate racial discrimination in the enjoyment of "the right to leave any country, including one's own, and to return to one's country."

37. American Convention, supra note 19, art. 22. Article 22(2) provides: "Every person has the right to leave any country freely, including his own."

38. Opened for signature 4 November 1950, entered into force 3 September 1953; 213 U.N.T.S. 222; reprinted in Council of Europe, Collected Texts, \$1, doc. 5 (1971). Article 2(2) provides: "Everyone shall be free to leave any country, including his own."

39. For a discussion of the principle of non-refoulement, see infra notes 66-83 and accompanying text. 


\section{B. The Right to Asylum}

The principle of asylum is crucial both to those seeking and to those already given refugee status. The Institute of International Law adopted in 1950 the following broad definition of asylum: "Asylum is the protection which a State grants on its territory or in some other place under the control of its organs, to a person who comes to seek it." 40 This definition encompasses both diplomatic and territorial asylum. Yet there is an important distinction between these two kinds of asylum. Diplomatic asylum occurs when a person seeks and is granted asylum in a legation, in an embassy, or on board a naval ship or military vessel lying withing the territorial jurisdiction of the state from which the person seeks refuge. Territorial asylum occurs when a person reaches or crosses the frontier of another state or when that person is already in another state and seeks and receives refuge therein. Of the two, territorial asylum is most directly relevant to aliens and refugees.

The origins of asylum date back to the right of sanctuary in ancient Greece and similar practices in imperial Rome and early Christian civilization. Neither form of asylum is compelled by international law, but rather is based on a state's recognition of a compelling humanitarian duty. Although it is arguable that the principle of territorial asylum, based on established tradition, has acquired the status of customary law in Latin America, it has not yet achieved the status of a universally accepted legal right. However, the right of an individual "to seek" asylum is set forth in several international human rights instruments.

Article 14 of the Universal Declaration proclaims that "[e]veryone has the right to seek and to enjoy in other countries asylum from persecution." 41 The right cannot be invoked, however, "in the case of prosecutions genuinely arising from non-political crimes or from acts contrary to the purposes and principles of the United Nations." 42 This right is similarly enumerated in Article 27 of the American Declaration, which states: "Every person has the right, in case of pursuit not resulting from ordinary crimes, to seek and receive asylum in foreign territory, in accordance with the laws of each country and with international agreements." 43 Further, the right to territorial asylum is made a binding legal obligation in Article 22(7) of the American Convention on Human Rights, which provides: "Every person has the right to seek and be granted asylum in a foreign territory, in accordance with the legislation of the state and international conventions, in the event he is being pursued for political offenses or related common crimes." 44 Proposals for the inclusion of similar provisions in the two International Covenants were

40. I Annuaire de I'Institut de Droit International, art. 1 at 167 (1950).

41. Universal Declaration, supra note 9, art. 14(1).

42. Id. art. 14(2).

43. American Declaration, supra note 10, art. 27.

44. American Convention on Human Rights, supra note 19, art. 22(7). 
rejected "partly because of the difficulty of reaching agreement on the categories of persons who should be granted asylum." 45

In 1951 the U.N. General Assembly took two major actions designed to provide greater protection to and to enlarge the rights of refugees - the creation of the Office of the U.N. High Commissioner For Refugees ${ }^{46}$ (U.N.H.C.R.) and the adoption of the Convention Relating to the Status of Refugees. ${ }^{47}$ The 1951 Convention and the 1967 Protocol ${ }^{48}$ thereto provide the most comprehensive codification of the rights of refugees under international law. Article 1 of the 1951 Convention defines a refugee as any person who, "owing to well-founded fear of being persecuted for reasons of race, religion, nationality, membership of a particular social group or political opinion, is outside the country of his nationality [or having no nationality, the country of his residence] and is unable or, owing to such fear, is unwilling to avail himself of the protection of that country ...." 49 As the U.N. itself notes, "the Convention is based upon two principles: (1) that there should be as little discrimination as possible between nationals, on the one hand, and refugees, on the other; and (2) that there should be no discrimination based on race, religion or country or origin among refugees." 50

Contracting parties to the Convention agree to accord refugees treatment at least as favorable as that granted to their own citizens regarding the exercise of basic rights, such as freedom of association, ${ }^{51}$ access to the courts $^{52}$ elementary education, ${ }^{53}$ and public assistance. ${ }^{54}$ Article 31 pro-

45. United Nations, The United Nations and Human Rights at 58 (1978).

46. Statute of the Office of U.N. High Commissioner for Refugees, adopted 14 December 1950; G.A. Res. 428 (V), 5 U.N. GAOR Supp. No. 20, U.N. Doc. A/1775; reprinted in 3 U.N. Resolutions, ser. 1, General Assembly 120-22 (D. Djonovich, ed. 1950-52). The U.N.H.C.R.'s major responsibilities in protecting refugees include: (1) promoting governmental and private efforts to promote voluntary repatriation or assimilation of refugees within new countries; (2) facilitating the admission of refugees to states; (3) assisting refugees to transfer their assets during and after resettlement; (4) promoting ratification of and state compliance with international agreements for the protection of refugees; and (5) working with governments to improve the situation of refugees and to reduce the number requiring protection.

47. Convention Relating to the Status of Refugees, adopted 28 July 1951, entered into force 21 April 1954; 189 U.N.T.S. 137 (1951) [hereinafter cited as 1951 Convention]. Adoption was by the U.N. Conference of Plenipotentiaries on the Status of Refugees and Stateless Persons, convened under G.A. Res. 429 (V), 14 December 1950.

48. Protocol Relating to the Status of Refugees, opened for signature 31 January 1967, entered into force 4 October 1967; 606 U.N.T.S. 268 [hereinafter cited as 1967 Protocol]. The 1951 Convention applied only to persons who became refugees before 1 January 1951. The 1967 Protocol removed this limitation, and afforded the protection of the Convention to all refugees, without geographic or time limitations. The United States signed and ratified the 1967 Protocol (it had not signed the 1951 Convention), which entered into force as to the U.S. on 1 November 1968. See 19 U.S.T. 6223.

49. 1951 Convention, supra note 47 , art. $1(A)(2)$.

50. United Nations, The United Nations and Human Rights at 57 (1978).

51. 1951 Convention, supra note 47 , art. 15.

52. Id. art. 16.

53. Id, art. 22(1).

54. Id, art. 23. 
vides the following safeguard to aliens who have surreptitiously entered the territory of a state party to the Convention:

The Contracting States shall not impose penalties, on account of their illegal entry or presence, on refugees who, coming directly from a territory where their life or freedom was threatened... enter or are present in their territory without authorization, provided they present themselves without delay to the authorities and show good cause for their illegal entry or presence. ${ }^{55}$

In 1954, certain member states of the O.A.S. signed at the Tenth InterAmerican Conference, held in Caracas, Venezuela, the Convention on Territorial Asylum, ${ }^{56}$ unquestionably the most advanced regional document of its kind. Article 1 states: "Every State has the right, in the exercise of its sovereignty, to admit into its territory such persons as it deems advisable, without, through the exercise of this right, giving rise to complaint by any other state." 57 Under Article 2, this right of admission extends to persons who in their country "are persecuted for their beliefs, opinions or political affiliations, or for acts which may be considered as political offenses." 58

Article 5 specifically provides that the mere fact "that a person has entered into the territorial jurisdiction of a State surreptitiously or irregularly does not affect the provision of this Convention." 59 By not excluding such persons from the enjoyment of guaranteed rights, the Convention explicitly recognizes the fact that persons fleeing from persecution are frequently forced by circumstance to leave their country clandestinely and to seek refuge in another by similar means.

In 1967 the U.N. General Assembly unanimously adopted and proclaimed the Declaration on Territorial Asylum, ${ }^{60}$ which recognizes that the granting of such asylum is a peaceful and humanitarian act and sets forth principles that should guide states in granting asylum. ${ }^{61} \mathrm{In}$ this regard, it affirms, in part, that (1) "Asylum granted by a State, in the exercise of its sovereignty, to persons entitled to invoke article 14 of the Universal Declaration of Human Rights .. . shall be respected by all other States," ${ }^{62}$ (2) that the right may not be invoked by any person who has committed "a crime against peace, a war crime or a crime against humanity, ${ }^{\prime 63}$ and (3) that the

55. Id. art 31(1) ("Refugees Unlawfully in the Country of Refuge"). Article 31(2) provides: "The Contracting States shall allow such refugees a reasonable period and all the necessary facilities to obtain admission into another country."

56. Convention on Territorial Asylum, opened for signature 28 March 1954, entered into force 29 December 1959; O.A.S. Treaty Series No. 34.

57. Id. art. 1 .

58. Id. art. 2.

59. Id. art. 5.

60. Declaration on Territorial Asylum of 14 December 1967; G.A. Res. 2203 (XXI), 21 U.N. GAOR Supp. No. 16, U.N. Doc. A/6316 (1967).

61. Id., preface to Declaration.

62. Id. art. 1(1).

63. Id. art. $7(2)$. 
State granting asylum is responsible for evaluating the grounds for its grant thereof. ${ }^{64}$ The significance of these and other provisions ${ }^{65}$ in the Declaration is that they further clarify the minimum standards implicit in the application of Article 14 of the Universal Declaration and, as such, should be followed by all states, whether or not they are contracting parties to the 1951 Convention Relating to the Status of Refugees and/or the 1967 Protocol thereto.

Despite the fact that these international instruments proclaim or guarantee the right to asylum, it is clear that the nature of this right in the individual is, at best, imperfect and conditional. These instruments do not purport to create a legally enforceable right in the individual to claim asylum, but rather reaffirm the right of the state to grant asylum. They do provide, however, significant legal safeguards and rights to persons who have been granted asylum.

\section{The Principle of Non-Refoulement}

Although the right to asylum has not yet attained universal recognition, the international community has generally accepted the principle of nonrefoulement as a binding rule. ${ }^{66}$ The classic formulation of this principle, which prohibits the expulsion or return of a refugee to the country from which he has fled, is found in Article 33 of the 1951 Convention:

1. No Contracting State shall expel or return ("refouler") a refugee in any manner whatsoever to the frontiers of territories where his life or freedom would be threatened on account of his race, religion, nationality, membership of a particular social group or political opinion.

2. The benefit of the present provision may not, however, be claimed by a refugee whom there are reasonable grounds for regarding as a danger to the security of the country in which he is, or who, having been convicted by a final judgement cf a particularly serious crime, constitutes a danger to the community of that country. ${ }^{67}$

64. Id. art. $1(3)$.

65. Id.

66. Guy Goodwin-Gill, former Legal Advisor to the U.N. High Commissioner on Refugees, has argued that "the prohibition on the return of refugees to countries of persecution has established itself as a general principle of international law, binding on States automatically and independently of any specific assent." G. Goodwin-Gill, International Law and the Movement of Persons Between States 141 (1978). Richard Plender, however, while supporting the concept of non-refoulement, argued in his 1972 book that it had not yet obtained the status of being a general principle of international law. "An examination of diplomatic practice does not support the view that non-refoulement has yet matured into a principle of international law. Nevertheless, it does demonstrate widespread acceptance of the unwisdom of returning political refugees, against their will, to the country from which they have fled." R. Plender, International Migration Law 244 (1972).

67. 1951 Convention, supra note 47, art. 33. ("Prohibition of Expulsion or Return ('Refoulement')" 
With regard to expulsion, article 32 provides that a refugee shall not be expelled except on grounds of national security or public order, ${ }^{68}$ and then only pursuant to a decision reached in accordance with due process of law, including the right of the refugee to give evidence himself and the right of appeal. 69 In case of expulsion, the refugee must be allowed a reasonable period within which to seek legal admission into another country. ${ }^{70}$

The inclusion of both words "expel or return" in article 33 is significant since "return" encompasses the case of a refugee who has arrived in or at the frontier of a state party to the Convention. Properly viewed, the prohibition against return should require a state party that is unwilling to grant such a refugee asylum (who otherwise satisfies the article's requirements) to accord him safe passage to another country or, perhaps, to expel him to another country disposed to receive him. Moreover, not only may a state party not directly expel a refugee to a country where he risks persecution, but similarly may not expel him to another country where there is a reasonable basis to believe that he would be returned subsequently to the country where he fears persecution. ${ }^{71}$ Thus, Article 33 prohibits any direct or indirect return or expulsion to the country of feared persecution. It is also noteworthy that Article 33, unlike other provisions in the Convention, makes no distinction between a refugee lawfully or unlawfully in the state party's territory. This article provides a crucial safeguard to refugees and, accordingly, no reservation to or derogation from it by a state party is permitted under the Convention. ${ }^{72}$

The principle of non-refoulement is included in many of the previously mentioned international instruments, as well as in other international and regional conventions on asylum and extradition. The 1954 Caracas Convention on Territorial Asylum provides in Article 3 that: "No state is under the obligation to surrender to another state or to expel from its own territory, persons persecuted for political reasons or offenses." ${ }^{73}$ The American Con-

68. Id. art. 32(1).

69. Id. art. 32(2). This provision applies "[e]xcept where compelling reasons of national security otherwise require...." Id.

70. Id. art. 32(3). The host state may, however, apply whatever internal measures it deems necessary during this period.

71. Id. art. 33(1).

72. Id. art. 42(1). "At the time of signature, ratification or accession, any State may make reservations to articles of the Convention other than to articles 1, 3, 4, 16(1), 33, 36-46 inclusive." Article 33 is the only major substantive provision in the Convention to which no exceptions are allowed, demonstrating the importance of non-refoulement to the drafters, and the unacceptability of any lesser standard. Of the other articles to which no reservation may be taken: Article 1 contains the definition of the term "refugee"; Article 3 is a nondiscrimination clause; Article 4 is a freedom of religion clause; Article 16(1) provides for free access to the courts; and Articles 36-46 are administrative clauses.

73. Caracas Convention on Territorial Asylum, 18 Pan-Am. T.S. Copies of all Inter-American treaties and conventions dealing with asylum and extradition have been reprinted in Trados y convenciones interamericanos sobre asilo y extradicion, Union Panamericana, Serie Sobre Tratados No. 34; O.A.S. Doc. OEA/Ser. X/7 (Espanol). English translations of 
vention on Human Rights makes the principle of non-return a legally binding rule on its signatories in article 22(8), which provides in language similar to that used in the 1951 Convention: "In no case may an alien be deported or returned to a country, regardless of whether or not it is his country of origin, if in that country his right to life or personal freedom is in danger of being violated because of his race, nationality, religion, social status, or political opinions." 74 Unlike provision 6 of the same article, which pointedly applies only to "aliens lawfully in the territory of a State Party," 75 section 8 specifically refers to "aliens" and thus makes no distinction between those aliens lawfully within a state and those who are not for purposes of the principle's application.

The 1967 U.N. Declaration on Territorial Asylum contains an important provision on non-refoulement. Article 3 declares that: "No person [entitled to invoke Article 14 of the Universal Declaration] shall be subjected to measures such as rejection at the frontier or, if he has already entered the territory in which he seeks asylum, expulsion or compulsory return to any State where he may be subjected to persecution." 76 This protection applies to all persons except "in the case of prosecution genuinely arising from nonpolitical crimes or from acts contrary to the purposes and principles of the United Nations." 77 It should be noted that Article 3's proscription against refoulement applies equally to rejection at a frontier and to return or expulsion of an alien who already has entered the country, whether legally or illegally. ${ }^{78}$

This principle is also embodied in Article 2 of the Organization of African Unity's 1969 Convention governing the Specific Aspects of the Refugee Problem in Africa (which specifically prohibits rejection at the frontier), ${ }^{79}$ in Article 3 of the Nansen Convention relating to the International

the treaties and conventions are available in Inter-American Treaties and Conventions on Asylum and Extradition, Pan-American Union, Treaty Series No. 34, O.A.S. Doc. OEA/Ser. X/l (English).

74. American Convention, supra note 19, art. 22(8).

75. Id. art. 22(6) (emphasis added).

76. U.N. Declaration on Territorial Asylum, supra note 60, art. 3(1) (emphasis added).

77. Id., preface to Declaration (quoting Article 14 of the Universal Declaration).

78. Unlike the American Convention, the Declaration on Territorial Asylum does not allow for exceptions to the non-refoulement provision. Article 3(2) of the Declaration provides, however, that an exception "may be made ... . only for overriding reasons of national security or in order to safeguard the population, as in the case of a mass influx of people." Declaration on Territorial Asylum, supra note 60, art. 3(2). Article 3(3) provides that should a state decide to make an exception to Article 1(1), it should consider granting the individual an opportunity, through provisional asylum or otherwise, of going to another state.

79. O.A.U. Convention Governing the Specific Aspects of Refugee Problems in Africa, Addis Ababa, opened for signature 10 September 1969, entered into force 20 June 1974; reprinted in International Legal Instruments on Refugees in Africa 118 (G. Melander \& P. Nobel eds. 1979). Article 2(3) provides: "No person shall be subjected by a Member State to measures such as rejection at the frontier, return or expulsion, which would compel him to return to or remain in a territory where his life, physical integrity or liberty would be threatened. ..." 
Status of Refugees (Geneva 1933), ${ }^{80}$ in Article 31 of the Final Act of the 1954 U.N. Conference of Plenipotentiaries, which adopted the Convention relating to the Status of Stateless Persons, ${ }^{81}$ in Article 3 of the European Convention on Extradition (1957), ${ }^{82}$ and in Article 3 of the legal principles governing the treatment of refugees adopted by the Asian-African Legal Consultative Committee in Bangkok in 1966. ${ }^{83}$

It is abundantly clear that the inclusion of the principle of nonrefoulement in both international and regional treaties, which impose legal obligations on signatories thereto, and in important declarations indicates that the principle has received widespread authoritative recognition throughout the world. As such, it appears that this principle has evolved from a basic humanitarian duty into a general principle of international law that binds all states, even in the absence of an express treaty obligation.

\section{Rights Conferred by the Helsinki Accords}

The United States and thirty-four other countries, including the state members of NATO and the Warsaw Pact, signed on 1 August 1975 the Final Act of the Conference on Security and Cooperation in Europe. ${ }^{84}$ Commonly known as the Helsinki Accords, this instrument is an agreement among the signatory states, elaborated in treaty language without being a treaty. ${ }^{85}$ Although the Accords do not create legally binding obligations, they nonetheless, according to Judge Thomas Buergenthal and other leading authorities, "must be interpreted by reference to relevant principles of inter-

80. Convention Relating to the International Status of Refugees, signed at Geneva 28 October 1933; 159 L.N.T.S. 199. Article 3 provides that a contracting state is "not to remove or keep from its territory by application of police measures, such as expulsions or non-admittance at the frontier (refoulement), refugees. ..."

81. Convention Relating to the Status of Stateless Persons, adopted 28 September 1954 by a Conference of Plenipotentiaries convened by ECOSOC Res. 526 A (XVII), 26 April 1954; 360 U.N.T.S. 117. Article 31(1) provides: "The Contracting States shall not expel a stateless person lawfully in their territory save on grounds of national security or public order."

82. European Convention on Extradition, 24 E.T.S.; 359 U.N.T.S. 273. Article 3(2) prohibits extradition where there is reason to believe that the request was made "for the purpose of prosecuting or punishing a person on account of his race, religion, nationality or political opinion, or that that person's position may be prejudiced for any of these reasons."

83. Asian-African Legal Consultative Committee, Principles Concerning Treatment of Refugees, adopted in Bangkok 8-17 August 1966; reprinted in International Legal Instruments on Refugees in Africa, supra note 79, at 374-83. Article 3(3) provides:

No one seeking asylum ... should [except for reasons of national security] be subjected to measures such as rejection at the frontier, return or expulsion which would result in compelling him to return to or remain in a territory if there is a well-founded fear of persecution endangering his life, physical integrity or liberty in that territory.

84. 73 U.S. Dep't of State Bull. 323; reprinted in 14 lnt'l Legal Mat. 1292 (1975).

85. See Buergenthal, "International Human Rights Law and the Helsinki Final Act: Conclusions," Human Rights, International Law and the Helsinki Accord 3-4 (T. Buergenthal ed. 1977). 
national law.... By incorporating and invoking preexisting principles of international law, the Helsinki Final Act confirms the adherence of the participating states to these principles and strengthens them to that extent." ${ }^{86} \mathrm{In}$ this regard, the Final Act contains specific human rights provisions in Principle 7 of the Declaration on Principles Guiding Relations between Participating States ${ }^{87}$ and in Basket III, entitled Cooperation in Humanitarian and Other Fields.

Principle 7 declares that " $t$ t] rights and fundamental freedoms, including the freedom of thought, conscience, religion or beliefs, for all without distinction as to race, sex, language or religion" and "will promote and encourage the effective exercise of civil, political, economic, social, cultural and other rights and freedoms." ${ }^{88}$ Further, signatory states "confirm the right of the individual to know and act upon his rights and duties" and pledge to act "in conformity with the purposes and principles of the Charter of the United Nations and with the Universal Declaration of Human Rights." Participating states are also bound to "fulfill their obligations as set forth in the international declarations and agreements in this field, including inter alia the International Covenants on Human Rights, by which they may be bound." Judge Buergenthal notes: "General Principle VII was acknowleged to be a statement of fundamental normative importance because it incorporates by reference a vast body of existing conventional and customary international human rights law and contains the undertaking of the signatory states to abide by this law." 89 Moreover, the reference specifically to the Universal Declaration tends to confirm the view that the basic right proclaimed therein has achieved the status of customary international law.

The human rights provision in Basket III are narrower and more specific in scope than those in Principle 7. The first section of Basket III declares the goal of signatory states "to facilitate freer movement and contacts, individually and collectively, whether privately or officially, among persons, institutions and organizations of the participating States, and to contribute to the solution of the humanitarian problems that arise in that connexion." 90 Included among the practical measures in Basket III to be complemented by appropriate domestic legislation are: (1) facilitation of travel by members

86. Id. at 6.

87. Final Act of the Conference on Security and Cooperation in Europe, supra note 84, at 1295 ("Questions Relating to Security in Europe; (a) Declaration on Principles Guiding Relations between Participating States; VII. Respect for human rights and fundamental freedoms, including the freedom of thought, conscience, religion or belief').

88. Id. at 1313.

89. Buergenthal, supra note 85 , at 8 .

90. Final Act of the Conference on Security and Cooperation in Europe, supra note 84, at 1313 (Basket III) ("Co-Operation in Humanitarian and Other Fields, §1 Human Contacts,' para. $5^{\prime \prime}$. 
of families in different countries; ${ }^{91}$ (2) reunification of family members by permitting emigration from the state of departure and immigration to the receiving state with "appropriate care with regard to employment for persons from other participating States who take up permanent residence in that State ... [and assurance] that they are afforded opportunities equal to those enjoyed by [signatories] own citizens for education, medical assistance and social security"; $; 2$ (3) grant of exit or entry permits to persons "who have decided to marry a citizen from another participating State"; 93 (4) facilitation of travel for personal and professional reasons; ${ }^{94}(5)$ promotion of tourism; ${ }^{95}$ (6) encouragement of meetings among young people through educational exchanges, professional training, foreign language study, and youth programs; 96 (7) expansion of sports meetings and competition; 97 and (8) exchange of information in all fields of knowledge. ${ }^{98}$

It is noteworthy that, although not stated as rights, emigration and immigration in the context of family reunification and the granting of exit and entry permits to facilitate transnational marriages are specific goals the signatory states have agreed in Principle 7 to promote and implement. Although emigration and immigration are not mentioned in Principle 7 , the right to emigrate, as previously noted, and other basic freedoms relevant to refugees and aliens arguably are incorporated by reference in Principle 7 since these basic rights are enumerated in the Universal Declaration and in other related international declarations and agreements. ${ }^{99}$

\section{UNITED STATES COMPLIANCE WITH INTERNATIONAL LEGAL STANDARDS RELATING TO ALIENS AND REFUGEES}

Prior to assessing the compatibility of existing United States immigration and related laws with relevant international law standards, it is important to note that, despite the fact that this country helped draft and has ratified the U.N. and O.A.S. charters, supported and voted for the Universal and InterAmerican Human Rights Declarations, and has been the leading spokesman for human rights around the world, the United States has one of the worst

91. Id. at 1313. ("1. Human Contacts, (1)(a) Contacts and Regular Meetings on the Basis of Family Ties").

92. Id. at 1374 ("(1)(b) Reunification of Families").

93. Id. at 1314 ("(1)(c) Marriage between Citizens of Different States").

94. Id. at 1314 ("(1)(d) Travel for Personal or Professional Reasons").

95. Id. at 1315 ("(1)(e) Improvement of Conditions for Tourism on an Individual or Collective Basis").

96. Id. at 1315 ("(1)(f) Meetings among Young People").

97. Id. at 1315 ("(1)(g) Sport").

98. Id. at 1315 ("(1)(2) Information").

99. See supra notes $85-87$ and accompanying text. 
records in the world for ratification of international human rights agreements. ${ }^{100}$

\section{A. United States Ratification of International Human Rights Treaties}

To date, the United States has ratified only the 1967 Protocol relating to the Status of Refugees; the 1956 Supplementary Convention on the Abolition of Slavery, the Salve Trade, and Institutions and Practices Similar to Slavery; and the Slavery Convention of 1926, amended by the 1953 Protocol. However, the United States has signed, but the Senate has not given its advice and consent to, the following international agreements: the Convention on the Prevention and Punishment of the Crime of Genocide (signed 1948), the Convention on the Elimination of All Forms of Racial Discrimination (signed 1966), and the American Convention on Human Rights, the Covenant on Civil and Political Rights, and the Covenant on Economic, Social and Cultural Rights, all signed by President jimmy Carter in 1977. Apart from ratifying the 1967 Protocol Relating to the Status of Refugees and signing the 1928 Havana Convention on Asylum, the United States has neither signed nor ratified any other regional or international convention affording explicit protections to refugees. In fact, when signing the 1928 Havana Convention on Asylum, ${ }^{101}$ the United States delegation did so with an explicit reservation which declared that the United States "does not recognize or subscribe to as part of international law, the so called doctrine of asylum." ${ }^{102}$

This poor record of ratification does not mean, however, that the basic human rights and freedoms guaranteed or proclaimed in these instruments do not apply to or have legal consequences for the United States and other states that are not parties to them. As previously noted, certain basic human rights and freedoms, once having attained a sufficient degree of universal recognition, have become rules of customary international law or general principles of law that are legally binding on all states. The U.S. government has explicitly accepted this view in its amicus brief in the Filartiga case. ${ }^{103}$ Moreover, the very fact that the United States has signed but not ratified certain conventions also creates certain legal obligations. Under an authoritative principle of treaty law, a state, on signing a treaty, is obliged to refrain from acts which could defeat the object and purpose of the treaty until that state makes clear its intention not to become a party to it. ${ }^{104}$

100. For a discussion of the U.S. record in ratification of international human rights agreements, see U.S. Ratification of the Human Rights Treaties. (R. Lillich ed. 1981).

101. 4 M. Hudson, International Legislation 2412-15 (1931).

102. Id. at 2415.

103. See supra notes $20-29$ and accompanying text.

104. Vienna Convention on the Law of Treaties, done at Vienna 22 May 1969, opened for 


\section{B. United States Immigration and Refugee Legislation}

The entry of aliens and refugees to and their exclusion from the United States are governed by the Immigration and Nationality Act ${ }^{105}$ and the Refugee Act of $1980 .{ }^{106}$ Both laws are obligations assumed beyond the international law principle that a state has an absolute right to exclude aliens from its territory. The criteria for admission and exclusion of aliens set forth in these acts are therefore beyond the scrutiny of international law, provided, however, that these criteria, either on their face or as applied, do not violate specific rules of international law that are binding on the United States.

1. The Immigration and Nationality Act. Sections 212(a)(27), (28) and (29) of the Immigration and Nationality Act, which provide for the exclusion of certain classes of aliens from the United States solely on ideological grounds, have been assailed as inconsistent with the spirit, if not the rules, of international law in this area. Section 212(a)(27) of the Act excludes aliens "who the consular officer or the Attorney General knows or has reason to believe seek to enter the United States solely, principally, or incidentally to engage in activities which would be prejudicial to the public interest, or endanger the welfare, safety, or security of the United States." 107 Section 212(a)(28) mandates the exclusion of aliens who are anarchists, who are in any way affiliated with the communist party, who advocate the doctrines of communism or the establishment in the United States of a totalitarian dictatorship, or who advocate "the overthrow by force, violence, or other unconstitutional means of the Government of the United States." 108

This section also excludes aliens who "write or publish, or cause to be written or published, or who knowingly circulate distribute, print, or display... or have in their possession ... any written or printed matter, advocating or teaching opposition to all organized government, or advocating or teaching ... the economic, international, and governmental doctrines of world communism." ${ }^{109}$ Section 212(a)(29) excludes aliens

whom the consular officer or the Attorney General knows or has reasonable ground to believe probably would, after entry, (A) engage in activities which would be prohibited by the laws of the United States relating to espionage, sabotage, public disorder, or in other activity subversive to the national security,

signature 23 May 1969; U.N. Doc. A/CONF.39/27 (1969), art. 18(a); reprinted in $63 \mathrm{Am}$. J. Int'l L. 875-903 (1969) ("Obligation not to defeat the object and purpose of a treaty prior to its entry into force").

105. Pub. L. No. 82-414, 66 Stat. 163 (1952) (codified in 8 U.S.C. $\$ \$ 1101-1254)$ (also referred to as the McCarran-Walter Act) [hereinafter cited as INA].

106. Pub. L. No. 96-212, 94 Stat. 102 (1980) (codified in 8 U.S.C. \$\$1101-1254) [hereinafter cited as Refugee Act of 1980].

107. INA, supra note 105, \$212(a)(27) (codified at 8 U.S.C. \$1182(a)(27) (1976)).

108. Id. §212(a)(28) (codified at 8 U.S.C. §1182(a)(28) (1976)).

109. Id. $\$ 212(a)(28)(G)$ (codified at 8 U.S.C. $\$ 1182(a)(28)(G)(1976)$ ). 
(B) engage in any activity a purpose of which is the opposition to, or the control or overthrow of, the Government of the United States, by force, violence, or other unconstitutional means, or (C) ... participate in the activities of any organization which is... required to be registered under section 7 of the Subversive Activities Control Act of 1950.110

While the attorney general or the secretary of state on the consular official's recommendation may waive the exclusionary grounds provided in section $212(a)(28),{ }^{111}$ neither he nor the secretary of state is empowered to recommend or approve such a waiver for aliens covered by section 212(a)(27) and (29). ${ }^{112}$

2. McGovern Amendment to the Immigration and Nationality Act. In August 1977 the Congress, citing the need for greater U.S. compliance with the provisions of the Helsinki Accords, passed the McGovern Amendment, which significantly liberalized waiver grants under section $212(a)(28) .^{113}$

The Amendment authorizes the secretary of state to recommend that the attorney general grant a waiver to an alien who is excludable because of membership in a proscribed organization, "unless the Secretary [of State] determines that the admission of such alien would be contrary to the security interests of the United States and so certifies to the Speaker of the House of Representatives and the chairman of the Committee on Foreign Relations of the Senate." 114 The Congress modified the McGovern Amendment in 1979 to prohibit the application of the liberalized waiver provisions to members or representatives of the Palestine Liberation Organization, and members of labor organizations that in fact are "instruments of a totalitarian state," and to permit the secretary of state to refuse to recommend waivers for "aliens from signatory countries which are not in substantial compliance with the provisions of the Helsinki Final Act, particularly the human rights and humanitarian affairs provisions." 115 David Carliner, a noted immigration law authority, has stated that while "[t]he effect of the McGovern Amendment was to remove some of the previous barriers to admission of aliens who had been denied visas on political grounds," the state department has avoided in certain cases "application of the provision in Section 212(a)(28) of the Amendment which required certification to Congress whenever a waiver was not recommended, however. They simply barred admission of aliens

110. Id. \$212(a)(29) (codified at 8 U.S.C. \$1182(a)(29) (1976)).

111. Id. $\$ 212(d)(3)$ (codified at 8 U.S.C. $\$ 1182(d)(3)(1976)$ ). See also id. $\$ 212(a)(28)(1)$ (codified at 8 U.S.C. $\$ 1182(a)(28)(1)(1976)$ ).

112. Id. $\$ 212(\mathrm{~d})(3)$ (codified at 8 U.S.C. $\$ 1182(d)(3)(1976)$ ).

113. Foreign Relations Authorization Act, Fiscal Year 1978, Pub. L. No. 95-105, §112, 91 Stat. 848 (1977).

114. Id. (subsequently amended; see infra note 117 and accompanying text).

115. Department of State Authorization Act, Fiscal Years 1980 and 1981, Pub. L. No. 96-60, $\S 109,93$ Stat. 397 (1979). 
under other provisions of the statute, namely Section 212(a)(27) or, in rare cases, Section 212(a)(29)." 116

Carliner charges that the current United States visa policy, insofar as aliens continue to be excluded under sections 212(a)(27), (28), and (29), fails to comply with this country's undertakings as a signatory to the Helsinki Final Act, particularly those provisions of Basket III on Cooperation in Humanitarian and Other Fields. ${ }^{117}$ Regarding Basket III provisions concerning family ties and family reunification, Carliner notes:

The provisions of the Immigration and Nationality Act which require exclusion of persons who are members of prescribed [sic] organizations do not permit waiver for spouses, children, or parents of United States citizens. The only grounds that a person who has been a member of a prescribed [sic] organization can assert for seeking admission to the United States as a permanent resident are that:

(1) such membership was "involuntary," while under the age of sixteen, by operation of law, or for the purpose of obtaining employment, food rations, or other essentials of living; or

(2) membership was terminated at least five years prior to the date of application for an immigrant visa and, in addition, he or she actively opposes the doctrines of the organization.

Persons who are able to establish these conditions, "to the satisfaction of a consular officer," must also obtain a determination by the Attorney General that their admission to the United States would be "in the public interest." Needless to say, these requirements exalt political doctrine above the principle of family reunification. 118

Carliner similarly perceives the anomaly between United States rhetoric and practice in facilitating marriage between citizens of different states, provided for in Basket III. United States condemnation of the Soviet Union's refusal to permit Russian fiances and spouses to emigrate, he notes, "is matched by the statute which forbids the admission to this country of spouses who have been voluntary members of proscribed organizations unless they have been engaged in active opposition to the doctrines of such organizations for a period of at least five years." 119

It is important to note, in connection with Carliner's observations, that United States failure to comply with specific human rights provisions of the Helsinki Final Act does not constitute a violation of international law since the Final Act is not legally binding on signatory states. ${ }^{120}$ However, if one accepts the view that the Final Act incorporates by reference preexisting

116. Carliner, "United States Compliance with the Helsinki Final Act: The Treatment of Aliens," 13 Vand. J. Transnat'l L. 397, 402 (1980).

117. Id. at 406 .

118. Id. at 407 .

119. Id. at 408.

120. See Buergenthal, supra notes $85-86$ and accompanying text. 
principles of international human rights law, then this country's noncompliance not only weakens the legitimacy of those principles, but similarly diminishes the credibility of United States commitment to promote their universal observance. Despite the fact that the exclusion of aliens for ideological and political reasons should be inimical to a democratic state and are wholly repugnant to the principle of freedom of thought, expression, and ideas, proclaimed in virtually all international human rights instruments, sections 212(a)(27), (28), and (29) do not contravene any rule of international law binding on the United States. As such, it is a permissible, albeit unflattering, expression of a sovereign's power to exclude aliens from its territory.

3. The Refugee Act of 1980 . The Refugee Act of $1980^{121}$ is the most significant legislative measure the Congress has undertaken to date to bring this country's laws into conformity with basic international law principles in the refugee area. ${ }^{122}$ Section 201(a) of the Act amends section 101(a) of the Immigration and Nationality Act by adding a new paragraph which defines the term "refugee" in language virtually identical to that used in Article 1 of the 1951 Convention Relating to the Status of Refugees and the 1967 Protocol thereto, to which the United States is a contracting party. ${ }^{123}$ By so doing, the Congress has directly incorporated an international definitional standard into U.S. law which should help reduce, in theory, the likelihood that determinations of refugee status under the Act will be inconsistent with this accepted international standard.

In addition, the Refugee Act eliminates some of the ideological and geographical distinctions established in previous legislation, particularly preferences for refugees from behind the Iron Curtain and from the Middle East. However, the 1980 Act indicates that, in connection with the admission of refugees of "special humanitarian concern to the United States," the

121. Pub. L. No. 96-212, 94 Stat. 102 (1980) (codified in 8 U.S.C. $§ \S 1101-1254$ ).

122. Senator Edward $M$. Kennedy, the original sponsor of the Refugee Act of 1980 , noted in the "Conference Report and Analysis of the Refugee Act of 1980": "This Act gives statutory meaning to our national commitment to human rights and humanitarian concerns - which are not now reflected in our immigration law." Report of the Senate Judiciary Committee, Review of U.S. Refugee Resettlement Programs and Policies $\mathbf{8 0}$ (1980) (text of the "Conference Report and Analysis of the Refugee Act of 1980" transmitted to the President).

123. The legislative history of the Refugee Act of 1980 indicates that it was the intention of Congress to bring the United States into closer compliance with the 1967 Protocol. In adopting a House version of an amendment to the 1980 Act, the Committee of the Conference noted that "[t]he Conference substitute adopts the House provision with the understanding that it is based directly upon the language of the Protocol and that it is intended to be construed consistent with the Protocol." Joint Explanatory Statement of the Committee of the Conference, H.R. Rep. No. 212, 96 Cong. 2d Sess. 20; reprinted in 1980 U.S. Code Cong. \& Ad. News 160, 161. For a thorough discussion of the legislative history of the Refugee Act of 1980, see Anker \& Posner, 19 San Diego L. Rev. 9-90 (1981). 
attorney general may not waive sections 212(a)(27), (29), and (33) of the Immigration and Nationality Act "with respect to such an alien for humanitarian purposes, to assure family unity, or when it otherwise would be in the public interest." 124 Thus an alien who satisfies the Act's definitional criteria for refugee status may nonetheless be effectively denied that status and admission to the United States on the basis of his political convictions and affiliations. In other words, whether or not an alien is "of special humanitarian concern" to this country may depend on his ideology.

If, as Congress states, one of its purposes in passing the Refugee Act was "to respond to the urgent needs of persons subject to persecution in their homelands [by] . . . humanitarian assistance for their care and maintenance in asylum areas . ..,"125 it is difficult to understand how this purpose is achieved by excluding such persons from entry to the United States under provisions of section 212(a)(27) and (29). Indeed, it is arguable that the ideological exclusion of aliens who otherwise would qualify for refugee status under section 201 of the Act constitutes a violation of the 1967 Protocol to the Convention Relating to the Status of Refugees on the ground that such exclusion is discriminatory and inconsistent with the object and purpose of the 1951 Convention and the Protocol.

Section 208 of the 1980 Act authorizes the attorney general to establish a procedure for receiving applications for asylum from "an alien physically present in the United States or at a land border or port of entry, irrespective of such alien's status. ..." ${ }^{126}$ The attorney general, at his discretion, may grant asylum if he finds the alien to be a refugee under the definition provided in the Act. ${ }^{127}$ A spouse or children of such an alien who is granted asylum under this provision, if not otherwise eligible for asylum, may be granted asylum if accompanying or following the admitted alien. ${ }^{128}$ This section appears to be in accord with the 1967 Protocol.

The principle of non-refoulement is specifically provided for in the new Refugee Act. Section 243(h) of the Immigration and Nationality Act has been amended to read as follows:

(h)(1) The Attorney General shall not deport or return any alien (other than an alien described in section 241(a)(19)) to a country if the Attorney General determines that such alien's life or freedom would be threatened in such country on

124. See Refugee Act of 1980 , supra note 106, §101(a), §207(c)(3).

125. Id. $\$ 101$ (a) (statement of purpose of the Act).

126. Id. §208(a) (emphasis added).

127. Id. The term "refugee" is defined in $\$ 101(\mathrm{a})(42)(\mathrm{A})$ of the 1980 Act as:

any person who is outside any country of such person's nationality or, in the case of a person having no nationality, is outside any country in which such person last habitually resided, and who is unable or unwilling to return to, and is unable or unwilling to avail himself or herself of the protection of, that country because of persecution or a well-founded fear of persecution on account of race, religion, nationality, membership in a particular social group, or political opinion.

128. Id. $\S 208(c)$. 
account of race, religion, nationality, membership in a particular social group, or political opinion.

(2) Paragraph (1) shall not apply to any alien if the Attorney General determines that -

(A) the alien ordered, incited, assisted, or otherwise participated in the persecution of any person on account of race, religion, nationality, membership in a particular social group, or political opinion;

(B) the alien, having been convicted by a final judgment of a particularly serious crime, constitutes a danger to the community of the United States;

(C) there are serious reasons for considering that the alien has committed a serious nonpolitical crime outside the United States prior to the arrival of the alien in the United States; or

(D) there are reasonable grounds for regarding the alien as a danger to the security of the United States. ${ }^{129}$

This language is substantially similar to that set forth in the nonrefoulement provision of the 1951 Convention Relating to the Status of Refugees and its 1967 Protocol. ${ }^{130}$ The inclusion of the words "deport or return" in section $243(\mathrm{H})(1)$ of the 1980 Act should be interpreted in a manner consistent with the "expel or return" phraseology of the 1951 Convention. ${ }^{131}$ In this regard, it is important to note that the prohibition by the 1951 Convention of expulsion of refugees applies equally to all aliens qualifying for refugee status, whether they are lawfully or unlawfully in a state party's territory. ${ }^{32}$ Accordingly, in the case of aliens who have entered the United States surreptitiously or seek asylum at its frontiers and who otherwise would qualify for admission as refugees, but are excluded for ideological reasons, their expulsion or return, directly or indirectly, to a country from which they have fled persecution would appear to violate both Article 31 and Article 33 of the 1951 Convention, both of which are binding legal obligations for the Untied States. The United States, both before and after passage of the 1980 Refugee Act, has not always observed the principle of non-refoulement in connection with the overall administration of its refugee and immigration laws and policies.

\section{RECOMMENDATIONS}

A major objective of the Congress in its ongoing review and reform of existing immigration and refugee laws and policies should be to bring these and future laws into conformity with existing international law standards in

129. Id. $\$ 203(\mathrm{e})$ (amending INA, supra note 105 , $2243(\mathrm{~h})(1))$ (to be codified at 8 U.S.C. $\S 1253(h)(1))$.

130. 1951 Convention, supra note 47, art. 33. ("Prohibition of Expulsion or Return ('Refoulement')"

131. For a discussion of the "expel or return" phraseology of the 1951 Convention, see supra notes $67-71$ and accompanying text.

132. See 1951 Convention, supra note 67 , art. 33 (non-refoulement provision) \& art. 31 ("Refugees Unlawfully in the Country of Refuge"). 
the area. The National Policy Panel of the United Nations Association of the U.S.A. in its Report of December 1979 properly observed that "[i]t is important that the United States incorporate evolving international conceptions or rights into its own jurisprudence, particularly as it so often urges other governments to accept enlarged standards of human rights." ${ }^{133}$ Since the protection and treatment of aliens and refugees forms part of contemporary international human rights law, the United States Senate should consent to the principal human rights conventions signed by President Jimmy Carter in 1977 , as well as other international instruments relating to aliens and refugees. Ratification will not only dissipate the embarrassing contradiction between our failure to formally subscribe to these conventions and our espousal of the basic rights guaranteed therein, but will enable the United States to participate in the organs established under these conventions to promote, protect, and fashion regional and international human rights.

In order to achieve these goals, the United States should take the following actions.

\section{A. General Recommendations}

1. The U.S. Senate should consent to the American Convention on Human Rights, the Convenant on Civil and Political Rights, the Covenant on Economic, Social and Cultural Rights, and the Convention on the Elimination of All Forms of Racial Discrimination. However, the Senate should not effectively dilute the legal effects of its accession to these international agreements by accepting all of the reservations, declarations, and understandings recommended by the U.S. state department in its letter accompanying the transmittal of these treaties to the Senate. ${ }^{134}$

2. Specifically, the Senate should reject the State Department's view that none of the substantive provisions in these four agreements is self-executing, i.e., not directly enforceable in U.S. courts without subsequent congressional legislation.

3. The President should sign and the Senate should consent to the Optional Protocol to the Covenant on Civil and Political Rights in order for the United States to accept the competence of the Human Rights Committee to receive and consider petitions from persons within the United States alleging violation by the United States of any right guaranteed in the Covenant.

4. The President should propose and the Senate accede to the compulsory jurisdiction of the Inter-American Court of Human Rights, estab-

133. United Nations Association of the United States of America, United States Foreign Policy and Human Rights at 40 (1979).

134. For a discussion of the proposed reservations to the American Convention on Human Rights, the Covenant on Civil and Political Rights, the Covenant on Economic, Social and Cultural Rights, and the Covenant on the Elimination of all Forms of Racial Discrimination, see U.S. Ratification of the Human Rights Treaties, supra note 100. The letter of transmittal accompanying the above agreements is reprinted in id., appendix at $\mathbf{8 5}$. 
lished by the American Convention, to enable persons injured by the United States to receive monetary compensation for such violations and to ensure that such rights will not continue to be violated in the future.

\section{B. Specific Recommendations}

1. Consistent with its obligations as a party to the 1967 Optional Protocol Relating to the Status of Refugees and as a signatory to the above noted four conventions, the Congress should repeal sections 212(a)(27), (28), and (29) of the Immigration and Naturalization Act and repeal and/or amend any section or provision of the Refugee Act of 1980 inconsistent with its obligations under international law.

2. With regard to individual asylum, (a) the President should sign and the Senate approve the 1954 Caracas Convention on Territorial Asylum. (b) The United States should press within the United Nations for a new international convention that would strengthen an individual's right to asylum.

3. The use of the terms "refugees" and "asylum" should be standardized in all existing and future United States legislation and patterned on United Nations definitions to simplify application procedures and admission guidelines for those aliens seeking refugee status or asylum within the United States.

4. The United States should seek within the United Nations a uniform definition of the principle of non-refoulement (no expulsion or return that would endanger a refugee), particularly as that principle applies to territorial asylum. In the meantime, the United States should apply that principle, as defined in Article 33 of the 1951 U.N. Convention Relating to the Status of Refugees and in the 1967 Protocol thereto, on a nondiscriminatory basis, to those refugees already within United States territory and to those refugees applying for such at its borders.

5. Pending new international conventions concerning immigration, the United States should not refuse to grant asylum to an alien simply because that alien has the opportunity to gain entry to another state. This principle should apply both to individual cases and those instances involving a public request by the U.N.H.C.R. for state support in emergencies.

6. The United States should urge, through United Nations clarification or addenda to existing agreements or protocols, the adoption of clear international standards that prohibit, except for certain narrow grounds, extradition of refugees to their country of origin, since to do so violates the right of free movement and asylum. 